УДК 65.012.12:33+658.0(477)

DOI: https://doi.org/10.37320/2415-3583/14.3

Бондарчук Н.В. доктор наук з державного управління, професор кафедри обліку, оподаткування та управління фінансово-економічною безпекою, Дніпровський державний аграрно-економічний університет

Міхіснко Д.В. магістр,

Дніпровський державний аграрно-економічний університет

\title{
УПРАВЛІННЯ ЕКОНОМІЧНОЮ БЕЗПЕКОЮ З УРАХУВАННЯМ ПОТРЕБ ВЛАСНИКІВ
}

\begin{abstract}
Констатовано, щуо економічна безпека може бути забезпечена тільки в тому разі, якщо буде визначена і побудована логічна система своєчасного виявлення, попередження $і$ ліквідації потенційних $і$ реальних економічних загроз і ризиків сталого розвитку підприємства з урахуванням потреб власників. Метою статті є визначення основ управління економічною безпекою з урахуванням потреб власників, формування механізму системи пріоритетних інтересів підприємства. Організація економічної безпеки підприємства залежить від того, наскільки ефективно воно здатне уникнути можливих загроз за окремими складниками зовнішнього та внутрішнього середовища. У статті розглянуто основні фактори, щзо виливають на стан економічної безпеки підприємства Констатовано, що формування механізму забезпечення економічної безпеки підприємства повинно відбуватися з урахуванням потреб власників підприємства за допомогою прийняття відповідних управлінських рішень, формування інформаційного поля, проведення аналітичних та прогнозних робіт, виконання низки економічних розрахунків та очінки отриманих результатів.
\end{abstract}

Ключові слова: економічна безпека, управління, механізм, підприємство, власники.

Постановка проблеми. Забезпечення економічної безпеки підприємства являє собою складну багатоцільову систему, зміст і структура якої залежить від фінансово-економічного стану підприємства і впливу на нього внутрішніх факторів та зовнішнього середовища. В умовах ринкових відносин кожен економічний суб'єкт діє самостійно, застосовуючи механізми, які сприяють наданню інформації про можливі негативні наслідки, загрози економічним інтересам, виникнення реальних і потенційних загроз.

Виходячи $з$ цього, економічна безпека може бути забезпечена тільки в тому разі, якщо буде визначена і побудована логічна система своєчасного виявлення, попередження і ліквідації потенційних і реальних економічних загроз та ризиків розвитку підприємства 3 урахуванням потреб власників.

Аналіз останніх досліджень та публікацій. Дослідження основних аспектів управління фінансово-економічною безпекою на підприємстві становлять здобутки іноземних та вітчизняних науковців, таких як: О.І. Барановський, Т.Г. Васильців, І.О. Бланк, К.С. Горячева, О.Б. Злотенко, С.С. Куперівська, О.В. Орлик, P.С. Папєхін, П.Я. Пригунов та інші. Теоретичні та практичні результати у дослідженні цього питання значні, але необхідно відзначити, що проблеми управління фінансово-економічною безпекою на підприємстві залишаються не досить вивченими.

Метою статті $\epsilon$ визначення основ управління економічною безпекою з урахуванням потреб власників, формування механізму системи пріоритетних інтересів підприємства.

Виклад основного матеріалу дослідження. Ефективне управління фінансово-економічною безпекою 3 урахуванням потреб та інтересів власників підприємства залежить від чіткого розуміння основного кате- горіального апарату, а саме: «економічна безпека», «загроза», «ризик», «оцінка».

Можна сказати, що безпека є ключовою цінністю в діяльності будь-якого підприємства. Тобто безпека - це благо, умова, яка дає змогу суб'єкту господарювання досягати поставлених цілей і мати можливість задовольняти потреби наступного рівня.

Під безпекою підприємства слід розуміти його захищеність від негативного впливу зовнішніх і внутрішніх загроз, дестабілізаційних факторів, внаслідок чого досягається стале функціонування та розвиток підприємства [4, с. 12].

Безпека може розглядатися з позиції реалізації та захисту економічних інтересів підприємства [1, с. 85].

Основними принципами економічної безпеки підприємства є законність і дотримання балансу інтересів, взаємна відповідальність персоналу та керівництва, взаємодія з органами законодавчої і виконавчої влади.

Організація економічної безпеки підприємства залежить від того, наскільки ефективно воно здатне уникнути можливих загроз за окремими складниками зовнішнього та внутрішнього середовища, основними з яких є:

1. Фінансовий складник, який відповідає за досягнення найбільш ефективного використання корпоративних ресурсів.

2. Інтелектуальний і кадровий складники, які становлять розвиток інтелектуального потенціалу підприємства, ефективне управління персоналом. Належний рівень економічної безпеки великою мірою залежить від складу кадрів, їхнього інтелекту та професіоналізму.

3. Технологічний складник. Рівень застосування технологій, які відповідають сучасним світовим аналогам щодо оптимізації витрат ресурсів.

4. Правовий складник. Правове забезпечення діяльності підприємства і дотримання чинного законодавства. 
5. Інформаційний складник. До основних функцій інформаційного складника належать: збір всіх видів інформації, яка має стосунок до діяльності підприємства; аналіз отриманої інформації з обов'язковим дотриманням загальноприйнятих заходів (систематизації, безперервності надходження і обліку) і методів організації робіт; можливість прогнозування тенденції розвитку технологічних, економічних і політичних процесів на підприємстві [2, с. 134].

Є безліч конкретних загроз і чинників, які впливають на рівень економічної безпеки, з якими підприємство стикається у процесі своєї діяльності. Розглянемо більш докладно загрози економічній безпеці підприємства, під якими слід розуміти зовнішні та внутрішні фактори, які впливають на конкурентоспроможність, ефективність та стійкість розвитку підприємства. Виявлення можливих загроз економічній безпеці та розроблення заходів щодо запобігання їм мають першочергове значення у системі забезпечення економічної безпеки вітчизняних підприємств.

Найбільш ймовірними зовнішніми загрозами економічній безпеці будь-якого підприємства, на локалізацію яких повинна бути спрямована діяльність державних органів влади, є:

1. Збільшення майнової диференціації населення i підвищення рівня бідності, що призводить до виникнення соціальної напруги та кризи. Досягнутий відносний баланс соціальних інтересів може бути порушений в результаті дії таких факторів, як: розшарування суспільства на вузьке коло багатих і переважну масу бідних, які не впевнені у своєму майбутньому; збільшення частки бідних верств населення у містах порівняно із селом, що створює соціальну і кримінальну напруженість; затримка виплати заробітної плати, зупинка підприємств тощо.

2. Деформованість структури вітчизняної економіки.

3. Зростання нерівномірності соціально-економічного розвитку регіонів. Найважливішими факторами цієї загрози є: об’єктивно існуючі відмінності у рівні соціально-економічного розвитку регіонів, наявність депресивних, кризових і відсталих в економічному відношенні районів на тлі структурних зрушень у промисловому виробництві, що супроводжуються різким зменшенням частки обробних галузей.

4. Криміналізація суспільства і господарської діяльності, яка викликана в основному такими факторами, як: зростання безробіття; зростання корупції в державних органах влади, можливість доступу кримінальних структур до управління певною частиною виробництва та їх проникнення в різні владні структури; ослаблення системи державного контролю, яке призводить до розширення діяльності кримінальних структур на внутрішньому фінансовому ринку, у сфері приватизації, експортно-імпортних операцій і торгівлі.

Основними причинами, які викликають виникнення зазначених загроз, є нестійкий фінансовий стан підприємств, несприятливий інвестиційний клімат, збереження інфляційних процесів та інші проблеми, пов'язані 3 фінансовою дестабілізацією в економіці. Запобігання або пом'якшення наслідків дій загроз економічній безпеці України вимагає визначення і моніторингу факторів, які підривають стійкість соціальноекономічної системи держави.

Зовнішні загрози економічній безпеці підприємства виникають за межами підприємства. Вони не пов'язані 3 його виробничою діяльністю. Як правило, це така зміна навколишнього середовища, яка також може завдати підприємству суттєвих збитків (рис. 1).

Поняття зовнішніх і внутрішніх загроз економічній безпеці для кожного підприємства будуть індивідуальні. Виділяють реальні загрози і потенційні, які можуть статися за якихось умов. Внутрішні загрози економічній безпеці підприємства пов'язані з господарською діяльністю підприємства. Вони зумовлені тими процесами, які виникають під час виробництва і реалізації продукції і впливають на результати ведення господарської діяльності [5].

Існують загрози, які цілеспрямовано створюються іншими суб'єктами або можуть виникнути стихійно.

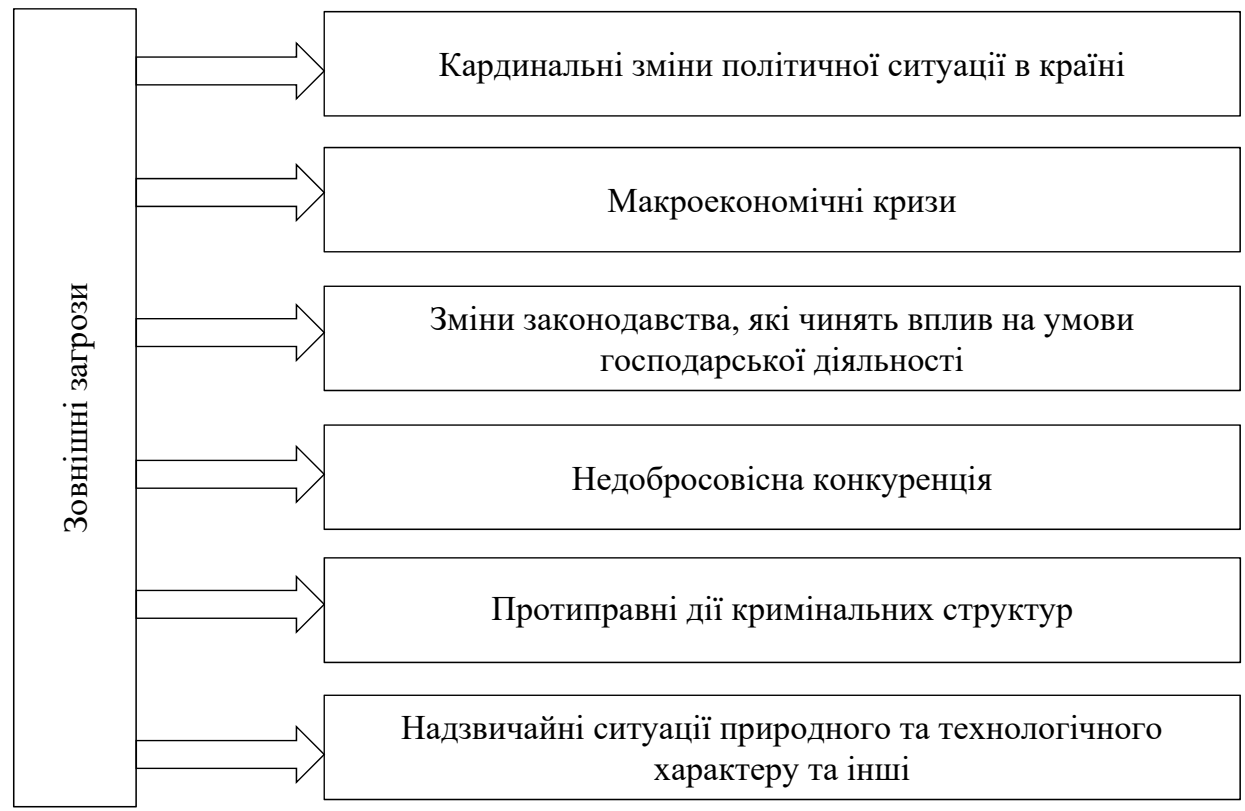

Рисунок 1 - Зовнішні загрози економічній безпеці підприємства 
Загрози можуть носити опосередкований характер, діяти за певних додаткових умов і виявлятися безпосередньо, прямо викликаючи негативні зміни. Розрізняють загрози, які породжують негативні зміни через короткі часові проміжки, і перспективні, прояв яких може наступити через тривалий період часу після виникнення загрози.

Рівень оцінки економічної безпеки підприємства i комплекс необхідних заходів щодо попередження небезпеки залежать від точної ідентифікації загроз, а також від правильного вибору дій. При цьому система економічної безпеки підприємства вимагає постійного аналізу та оновлення. 3 метою надання оцінки стану економічної безпеки підприємств треба провести аналіз та діагностику фінансово-економічної діяльності, на основі якого всебічно досліджуються технологічний рівень виробництва, якість та конкурентоспроможність продукції, забезпеченість матеріальними, трудовими, фінансовими ресурсами. Аналіз фінансово-економічного стану підприємства відображає всі сторони та характери його економічної діяльності та фінансові результати, поєднує ретроспекцію, діагноз та прогнозування перспективного або можливого стану. Під час оцінки стану економічної безпеки поряд із такими методами, як експертний, рейтинговий, факторний, статистичний доцільно використовувати метод моніторингу стану підприємства, який відрізняється постійністю, систематизацією, детальним поточним спостереженням за фінансово-економічним станом підприємства.

Цілі моніторингу загроз економічній безпеці підприємства:

- оцінка стану та динаміки розвитку підприємства;

- виявлення негативних тенденцій в різних сферах діяльності підприємства;

- визначення основних причин, характеру, інтенсивності, впливу загроз економічній безпеці підприємства;

- прогнозування наслідків дії загроз економічній безпеці підприємства;
- вивчення ситуації, що склалася, та тенденції іiі розвитку, розроблення заходів з усунення загроз економічній безпеці підприємства.

Таким чином, на наш погляд, моніторинг загроз економічній безпеці підприємства $є$ безперервною діагностикою діяльності підприємства за системою показників, які мають враховувати специфічні галузеві особливості цього сегменту, найбільш характерні для цього підприємства, і мають для останнього важливе стратегічне значення 3 метою завчасного попередження внутрішніх і зовнішніх загроз економічній безпеці та вжиття необхідних заходів захисту і протидії.

Рівень економічної безпеки підприємства залежить від того, наскільки швидко і грамотно його керівництво і фахівці зможуть відреагувати на наявні загрози і ліквідувати їхні шкідливі наслідки. Тому моніторинг загроз економічній безпеці підприємства є спільною роботою всіх зацікавлених працівників підприємства. Моніторинг проводиться за певний період часу діяльності підприємства, з урахуванням фактичного стану і тенденцій його розвитку, а також загального стану економіки, політичної обстановки та дії інших загальносистемних і соціальних факторів.

Таким чином, моніторинг загроз економічній безпеці підприємства дає змогу досліджувати комплекс факторів, що впливають на рівень економічної безпеки підприємства, проаналізувати динаміку соціально-економічних змін, провести техніко-економічне обгрунтування прийнятих управлінських рішень.

Формування механізму забезпечення економічної безпеки підприємства повинно відбуватися з урахуванням потреб власників підприємства за допомогою прийняття відповідних управлінських рішень, формування інформаційного поля, проведення аналітичних та прогнозних робіт, виконання низки економічних розрахунків та оцінки отриманих результатів.

Перелік завдань, які вирішуються за допомогою забезпечення економічної безпеки підприємства:

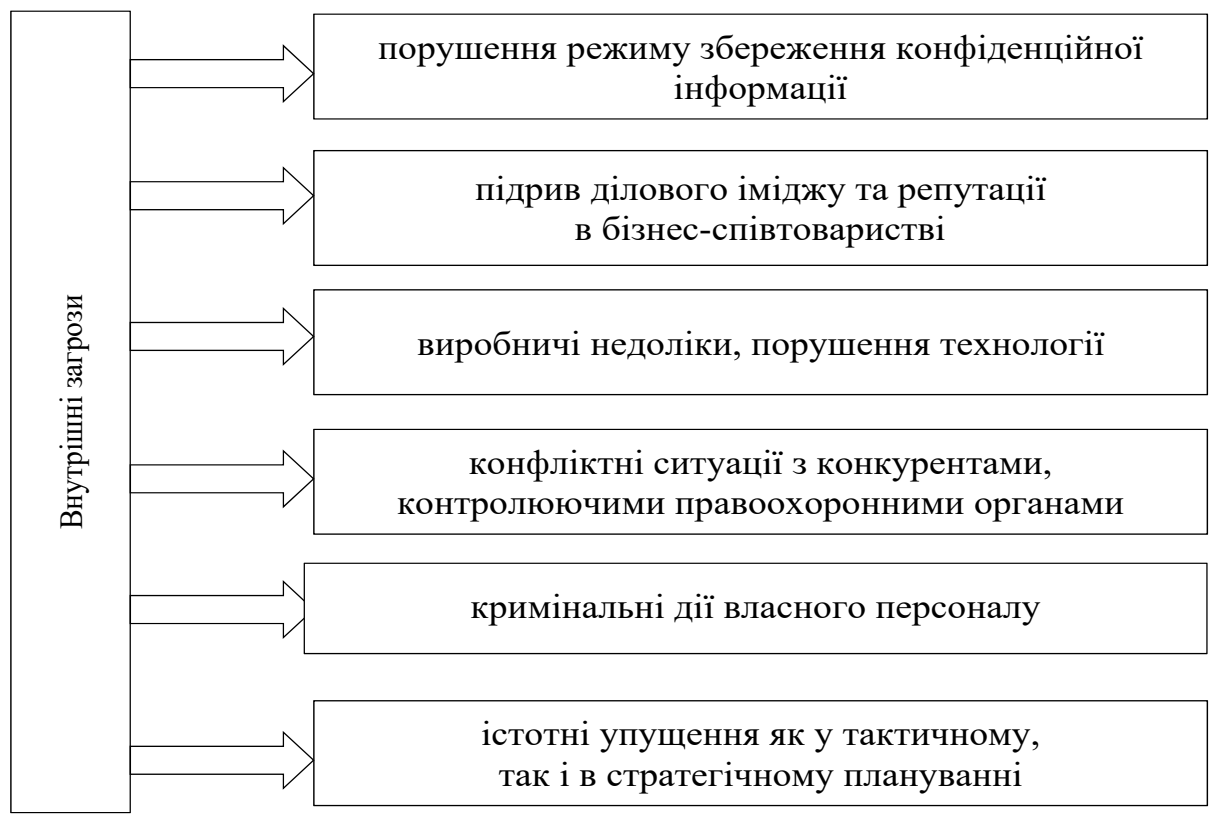

Рисунок 2 - Внутрішні загрози економічній безпеці підприсмства 
- забезпечення відповідності місії підприємства та стратегічних цілей його діяльності в системі пріоритетних цілей підприємства;

- визначення та оперативне коригування пріоритетів у діяльності підприємства та створення умов для їх реалізації;

- забезпечення відповідності обсягу продажу підприємства його ресурсному потенціалу та ємності ринку;

- забезпечення внутрішнього збалансування в діяльності підприємства;

- зниження ризику в діяльності підприємства;

- забезпечення зацікавленості персоналу в ефективній діяльності підприємства;

- створення гнучкої системи резервування підприємства;

- визначення можливості настання фази неефективного розвитку підприємства та його коригування на основі розробленої програми санації підприємства.

У системі економічної безпеки насамперед захисту потребують фінансові інтереси підприємства, які безпосередньо впливають на зміст механізму забезпечення фінансової безпеки. Фінансово-економічні інтереси підприємства - це його об'єктивні потреби у сфері фінансово-економічної діяльності, задоволення яких забезпечує реалізацію головних цілей його фінансово- економічного розвитку на кожному з етапів життєвого циклу. Фінансово-економічні інтереси підприємства не залишаються незмінними протягом його господарської діяльності, а уточнюються на всіх етапах його життевого циклу [5, с. 28].

Формування системи пріоритетних інтересів підприємства наведено на рис. 3.

Під час формування інтересів підприємства важливо враховувати часовий аспект, тобто мають бути враховані не тільки тактичні інтереси підприємства, а й стратегічні.

Пріоритетні інтереси підприємств мають бути виокремлені на основі їхнього рейтингу, що дасть змогу більш чітко сформулювати інтереси підприємства. До системи пріоритетних інтересів підприємства мають входити ті, які мають найвищий рейтинг.

3 метою оцінювання результатів діяльності підприємства за умови повного дотримання інтересів доцільно використовувати такі показники, які застосовують у практиці планування та обліку результатів діяльності підприємства, статистичній звітності та аналітичній роботі.

Системний підхід до формування механізму оцінки стану економічної безпеки підприємства передбачає, що необхідно враховувати всі реальні умови його діяльності, а саме механізм повинен мати чітко визна-

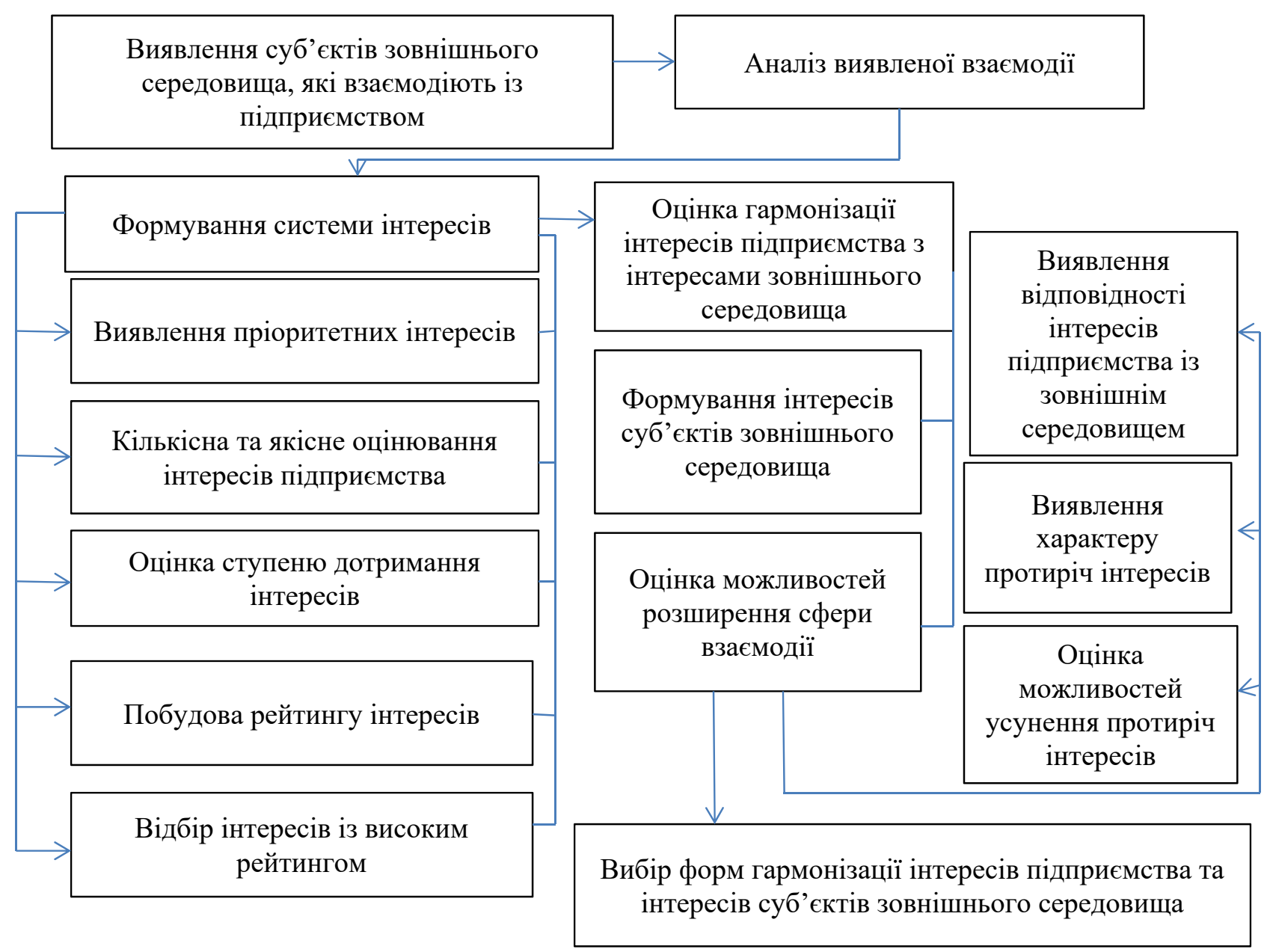

Рисунок 3 - Механізм формування системи пріоритетних інтересів підприємства 
чені елементи, схему їх взаємодії. Такий механізм повинен включати в себе структуру, яка містить в собі такі блоки, як: вхідний, внутрішній та вихідний.

Вхідний та вихідний блоки показують взаємодію підприємства із суб'єктами зовнішнього середовища. Внутрішній блок розкриває інформацію щодо факторів внутрішнього середовища; матрицю розподілу ресурсів за напрямами їх використання; розроблення схеми усунення невідповідності величини ресурсів обсягом продажу підприємства; аналіз адаптації підприємства до можливих нововведень тощо.

Висновки. Механізм забезпечення економічної безпеки підприємства з урахуванням потреб власників повинен забезпечити безпеку підприємства залежно від особливостей фінансово-економічної діяльності підприємства. У зв'язку із цим одним з елементів механізму має бути оцінка економічної безпеки підприємства $з$ урахуванням його основних інтересів.

\section{Список використаних джерел:}

1. Бабіна Н.О. Управління економічною безпекою підприємства в умовах кризового розвитку. Економіка та управління. 2014. № 1. C. 81-85.

2. Злотенко О.Б., Рудніченко С.М. Формування стратегічної складової забезпечення економічної безпеки інвестиційної діяльності промислового підприємства. Економіка. Інвестиційні процеси. 2019. №4. С. 131-138.

3. Козаченко А.В., Пономарев В.П. Методические основы оценки уровня экономической безопасности предприятия. Региональные перспективы. 2010. № 2-3 (9-10). С. 104-106.

4. Корчевська Л.О., Деменська А.М. Концептуальні підходи до визначення економічної безпеки підприємства. Наукововиробничий журнал «Навігатор». 2011. № 3 (24). С. 10-15.

5. Мойсеєнко І.П., Марченко О.М. Управління фінансово-економічною безпекою підприємства. Львів : ЛьвДУВС, 2011. 380 с.

6. Надьон Г.О. Криза в діяльності підприємства: діагностика та подолання : монографія. Луганськ : СНУ ім. В. Даля, 2010. $384 \mathrm{c}$.

7. Науменко Є.Ю. Механізм управління економічною безпекою підприємства в умовах кризи. Молодий вчений. 2017. № 6 (46). C. 462-466.

8. Орлик О.В. Механізм управління фінансово-економічною безпекою підприємства та його основні складові. Фінансовокредитна діяльність: проблеми теорії та практики. 2015. Вип. 2. С. 222-232.

9. Преображенська О.С. Особливості управління фінансово-економічною безпекою підприємства. Глобальні та національні проблеми економіки. 2015. Вип 3. С. 384-387.

\section{References:}

1. Babina N.O. (2014) Upravlinnya ekonomichnoyu bezpekoyu pidpryyemstva v umovakh kryzovoho rozvytku [Management of the economy-free enterprise in the minds of the crisis development]. Economics and management, vol. 1, pp. 81-85.

2. Zlotenko O.B., Rudnichenko E.M. (2019) Formuvannya stratehichnoyi skladovoyi zabezpechennya ekonomichnoyi bezpeky investytsiynoyi diyal'nosti promyslovoho pidpryyemstva [Formation of a strategic component of ensuring economic security of investment activity of an industrial enterprise]. Economy. Investment processes, no. 4, pp. 131-138.

3. Kozachenko A.V., Ponomarev V.P. (2010) Metodicheskiye osnovy otsenki urovnya ekonomicheskoy bezopasnosti predpriyatiya [Methodical bases of an estimation of a level of economic safety of the enterprise]. Regional perspectives, no. 2-3, pp. 104-106.

4. Korchevska L.O., Demenska A.M. (2011) Kontseptual'ni pidkhody do vyznachennya ekonomichnoyi bezpeky pidpryyemstva [Conceptual approach to the value of the economic security of the enterprise]. Scientific-production journal «Navigator», no. 3 (24), pp. 10-15.

5. Moiseenko I.P., Marchenko O.M. (2011) Upravlinnya finansovo-ekonomichnoyu bezpekoyu pidpryyemstva [Management of financial and economic security of the enterprise]. Lviv : LvDUVS. (in Ukranian)

6. Nadion G.O. (2010) Kryza v diyal'nosti pidpryyemstva: diahnostyka ta podolannya [Crisis in the enterprise: diagnosis and overcoming]. Luhansk : SNU named after V. Dalya. (in Ukranian)

7. Naumenko E.Yu. (2017) Mekhanizm upravlinnya ekonomichnoyu bezpekoyu pidpryyemstva v umovakh kryzy [The mechanism of management of economic security of the enterprise in the conditions of crisis]. Young scientist, no. 6 (46), pp. 462-466.

8. Orlik O.V. (2015) Mekhanizm upravlinnya finansovo-ekonomichnoyu bezpekoyu pidpryyemstva ta yoho osnovni skladovi [The mechanism of financial and economic security management of the enterprise and its main components]. Financial and credit activities: problems of theory and practice, vol. 2, pp. 222-232.

9. Preobrazhenskaya O.S. (2015) Osoblyvosti upravlinnya finansovo-ekonomichnoyu bezpekoyu pidpryyemstva [Features of financial and economic security management of the enterprise]. Global and national economic problems, vol. 3, pp. 384-387.

Bondarchuk Nataliia, Mikhienko Dmitriy Dnipro State Agrarian and Economic University

\section{ECONOMIC SECURITY MANAGEMENT TAKING INTO ACCOUNT THE OWNERS 'NEEDS}

Economic security can be ensured only if a logical system of timely detection, prevention and elimination of potential and real economic threats and risks of sustainable development of the enterprise, taking into account the needs of owners, is defined and built. The purpose of the article is to determine the basics of economic security management taking into account the needs of owners, the formation of the mechanism of the system of priority interests of the enterprise. In the course of the research general scientific research methods were used The main principles of economic security of the enterprise are legality and observance of balance of interests, mutual responsibility of the personnel and the management, interaction with bodies of legislative and executive power. The organization of economic security 
of the enterprise depends on how effectively it is able to avoid possible threats to certain components of the external and internal environment, the main of which are: financial, intellectual, technological, legal, information. The formation of the mechanism of economic security of the enterprise takes into account the needs of enterprise owners through appropriate management decisions, the formation of the information field, analytical and forecasting work, a number of economic calculations and evaluation of the results. The tasks which are solved by means of maintenance of economic safety of the enterprise are defined: maintenance of conformity of mission of the enterprise and the strategic purposes of its activity in system of the priority purposes of the enterprise; definition and operative adjustment of priorities in activity of the enterprise and creation of conditions for their realization; ensuring compliance of the company's sales volume with its resource potential and market capacity; ensuring internal balance in the activities of the enterprise; risk reduction in the enterprise; ensuring the interest of staff in the effective operation of the enterprise, etc. Mechanisms to ensure the economic security of the enterprise should allow to ensure the economic security of the enterprise depending on the characteristics of financial and economic activities of the enterprise. Therefore, one of the elements of the mechanism should be an assessment of the economic security of the enterprise, taking into account its main interests.

Key words: economic security, management, mechanism, enterprise, owners.

JEL classification: M20, M21 